DOI https://doi.org/10.30525/978-9934-26-110-7-17

\title{
ОДЕСЬКИЙ МІСЬКИЙ ТЕКСТ У НАЦІОНАЛЬНОМУ КОНТЕКСТІ (ЗА РОМАНОМ Й. КОЗЛЕНКА «ТАНЖЕР»)
}

\author{
Орманжи В. С. \\ аспірантка філологічного факультету \\ Запорізький наиіональний університет \\ м. Запоріжжя, Украӥна
}

Образ Одеси у вітчизняній літературі ще досі неоднозначний, адже в усталеному уявленні про місто українська ідентичність поступається російській та єврейській. Й. Козленко в романі «Танжер», вперше опублікованому 2007 р. у часописі «Київська Русь», вибудовує нову парадигму одеського літературного міту, вписуючи його в національний контекст [див. 5]. Окремою книжкою твір вийшов лише 2017 р. - в перевиданні під однією палітуркою з романом вміщено післямову автора й важливі для розуміння контексту додатки (уривки «Майстра залізної троянди» М. Бажана, «Все, що залишилось» Г. Островського й новелу «В листопаді» Ю. Яновського). Відредагований передрук був помічений критиками: Т. Калитенко, А. Кухар, Ю. Стахівською, Г. Улюрою, а от спроби літературознавчого аналізу поодинокі (І. Ткаченко, I. Томбулатова, О. Шупта-В'язовська) й стосуються передовсім першої версії роману.

Мета розвідки полягає в окресленні особливостей одеського міського тексту в романі Й. Козленка «Танжер».

За сюжетом студентові Оресту надходить пропозиція знятися у фільмі, сценарій якого $є$ вільною інтерпретацією заснованого на реальних подіях і водночас експериментального роману Ю. Яновського «Майстер корабля». Робота супроводжується зануренням у світ чуттєвих насолод, зокрема йдеться про гомоеротичні мотиви. Однак за суперечливим (i навіть скандальним) сюжетом приховано ключовий образ усього твору - i це образ міста, котрий концентрує на собі увагу як автора, так і читача. У післямові Й. Козленко відзначає, що «писав текст про багатонаціональний та строкатий мегаполіс, такий собі атавізм у зануреній у морок націоналізмів міжвоєнній Європі; приречене на загин благословенне місто, що відчайдушно захищає свої кордони... Трагічно уніфіковане й тотально радянізоване, на зламі століть воно стало безбарвним і анемічним, втратило нестримну творчу снагу» [2, с. 194]. Одеса, безумовно, стає осердям оповіді й поряд зі створенням 
«українського одеського міфу» (на противагу російському), автор формулює й ключові риси одеського тексту.

На думку Г. Улюри [6], «Голівуд на березі моря» реалізується в трьох іпостасях: місто-зустріч, місто-пам'ять, місто-фікція. Причому зовнішній образ топосу лишається незмінним, змінюється його прочитання: зустріч як новий етап, новий пошук, вічна оновлюваність (і юність) передусім пов'язана з перебігом подій; пам'ять про пошук, жагу нових відчуттів (обов'язково - дорослішання); фікція - 3 самого початку приречений на провал пошук ідеалу, довершеності. Потрійність у трактуванні зовсім не дивує, адже й хронологічно місто постає в різних часових площинах, через їхній взаємозв'язок розкривається спадковість комплексу проблем, властивих різним поколінням.

Важлива метафора закладена в назві твору: Танжер - це оспіване В. Берроузом марокканське місто-порт, яке тривалий час перебувало від владою різних держав (а отже не мало власної ідентичності); осередок культури бітників. Аналогія поглиблюється епіграфом (з того ж таки В. Берроуза): «Танжер, здається, існує одночасно в кількох вимірах... Тут дійсність переходить у сон, а сни вивергаються в реальність. Ніхто в Танжері не є тим, на що він зовні схожий... Ви у заповіднику невтручання» [3, с. 9]. Багатовимірною Й. Козленко описує й Одесу, переплітаючи кілька різних творів і художніх реальностей: 3 одного боку - «Майстер корабля» Ю. Яновського, уривки з мемуарів, подані в додатках; з іншого - текст «кіносценарію», поезії Ореста та весь роман як компіляція.

Хоча назва твору глибоко символічна, сам він напрочуд тілесний, сповнений візуальних, слухових, смакових, тактильних відчуттів. Від початку автор уводить образи моря й степу: Орест «губами відчував солонавий присмак морської води», «як усі степовики, він мав засмаглу шкіру й темне волосся», адже «діти степу повільно випікаються на сонці» [3, с. 11]. Море й степ у романі - символи природності, це дві могутні взаємозалежні стихії, у лоні яких народжуються незвичайні люди (і топоси). I хоча це ще не місто, але саме через природні об'єкти розкривається його істинний характер - внутрішня сила й краса, стихійність і вітаїстичність (тим більше, йдеться про 20-ті рр. ХХ ст.).

Характерно, що Одеса ніколи не описується й не осмислюється як індустріальне місто - цей аспект урбаністичного середовища їй абсолютно невластивий. На противагу величній естетиці природного пейзажу, людні місця сповнені фальші, зайвих розмов, брудних натяків. Це стосується й нудистського пляжу, й арт-кафе, і нічного клубу. Недарма ми бачимо, що Орест дратується поряд з чужими людьми: 
«...нудився: через надмір людей, фізичну близькість чужих тіл, беззмістовний белькіт голосів» [3, с. 18]. Кожен дотик у романі сповнений відчуттів (позитивних чи негативних), і лише контакт із близькими приносить насолоду.

3 самого початку бачимо, що стосунки головного героя 3 містом подібні до інтимних: усамітнені пляжі, вулички, сховок на ринку, піші прогулянки між занедбаними особняками творять незвичний образ Одеси, крізь який видніються образи живої історії: «...ВЕЛИЧЕЗНЕ ЛЮДСЬКЕ ВІЙСЬКО. ВОНО СУНЕ БУЛЬВАРОМ, АЛЕ, СТРИМУВАНЕ ЯКОЮСЬ НАДПРИРОДНОЮ СИЛОЮ, ЛИШАЕТЬСЯ В ЙОГО МЕЖАХ» [3, с. 22]. Історична Одеса, роздерта внутрішніми й зовнішніми протиріччями, трагічна у своїй боротьбі за власну ідентичність протиставляється звичному комедійному образу міста відпочивальників та торговців. До речі, тому численні авторські екскурси в історію, примітки по пів сторінки відіграють важливу роль у тексті. Навпаки, зайвою виглядає любовна лінія між Орестом, Мартою та Гордієм. Поряд із «першоджерелом» - емоційним зв'язком між Гео, Сашком та Ітою (Ю. Яновським, С. Довженком та Ітою Пензо) трикутник між представниками сучасної богеми виглядає брудно й гротесково, він сповнений зради та омани.

Насправді «Танжер» реалізований як текст про місто, людина в ньому - лише засіб, інструмент для цікавого експерименту. Безумовно, погляд на Одесу $\epsilon$ нетривіальним, але спроба розкриття психології цього оманливо безтурботного топосу не змінює й властивих йому зовнішніх характеристик: гамірності, багатолюдності, постійного руху й комунікації. Проте йдеться про природність цього руху. Так, опис «Сьомого кілометру» асоціюється з річковою течією: «На Синій вулиці течія була стрімкішою, ніж біля входу на майданчик... Швидкість руху залежала суто від щільності потоку» [3, с. 81]. Нагромадження звуків передається численними ампліфікаціями [див : 3, с. 82], адже «сотнями голосів бринів натовп» [3, с. 82]. Бачимо, що кожен елемент образу Одеси звичний (будь то море, степ, базар чи Дерибасівська), але кожен із них набуває інтимного значення в рецепції персонажів, кожен із них пов'язаний із тривалим культурно-історичним контекстом та уведений в текст як самостійна одиниця.

Міський текст, як наслідок, теж переосмислюється й сакралізується (принаймні та частина, у якій описується початок минулого століття). Сучасна Одеса приховує свою давню велич і трагедію за зовнішньою бездумністю, яскравим мерехтінням нічного життя. І водночас гротескові стосунки, пародія на справжні почуття, стають іiі уособленням. 
Отже, Й. Козленко у романі «Танжер» робить досить вдалу спробу повернути міф про Одесу до українського культурного контексту, про що свідчать розлогі історичні довідки й доповнення. Неодмінного переосмислення зазнає й одеський міський текст, сприйняття котрого залежить від включення до конкретної культурної парадигми. У художньому просторі «Танжеру» топос Одеси репрезентує не так колоніальну свідомість, як боротьбу проти неї, намагання вирватися із затісної традиції. Це вільний простір, відокремлений від іншого світу, відверто романтизований та ілюзорний.

Виразно зміщені акценти надають новизни образу міста й девульгаризують його. Звичні місця постають 3 різних ракурсів, набирають метафоричності, тож, попри топографічно точні описи, Одеса перетворюється на символічний простір - і саме це ріднить ії з легендарним Танжером. На нашу думку, тема потребує детальнішого вивчення та містить значний потенціал для аналізу.

\section{Література:}

1. Калитенко T. Де Одеса, а де Танжер? Новий роман Йвана Козленка. Комора: веб-сайт. URL: http://surl.li/ywvw (дата звернення: 05.07.2021)

2. Козленко Й. Нерв Танжера [післямова]. Танжер. К. : ВД «Комора», 2018. С. 185-197.

3. Козленко Й. Танжер. К. : ВД «Комора», 2018. 252 с.

4. Кухар А. «Танжер»: робота над контекстом. ЛітАкиент : вебсайт. URL: http://surl.li/ywwb (дата звернення: 06.07.2021)

5. Стахівська Ю. Йван Козленко «Танжер» [рецензія]. Критика: веб-сайт. URL: https://krytyka.com/ua/reviews/tanzher (дата звернення: 05.07.2021)

6. Улюра Г. «Танжер»: полювання у заповіднику. LB.ua : веб-сайт. URL: http://surl.li/ywwi (дата звернення: 04.07.2021) 